\title{
Pancreatic islet inflammation: an emerging role for chemokines
}

\author{
J Jason Collier1,2, Tim E Sparer ${ }^{3}$, Michael D Karlstad² and Susan J Burke ${ }^{4}$ \\ 'Laboratory of Islet Biology and Inflammation, Pennington Biomedical Research Center, Baton Rouge, \\ Louisiana, USA \\ 2Department of Surgery, Graduate School of Medicine, University of Tennessee Health Science Center, \\ Knoxville, Tennessee, USA \\ ${ }^{3}$ Department of Microbiology, University of Tennessee, Knoxville, Knoxville, Tennessee, USA \\ ${ }^{4}$ Laboratory of Immunogenetics, Pennington Biomedical Research Center, Baton Rouge, Louisiana, USA
}

Correspondence

should be addressed

to J J Collier

Email

Jason.collier@pbrc.edu

\begin{abstract}
Both type 1 and type 2 diabetes exhibit features of inflammation associated with alterations in pancreatic islet function and mass. These immunological disruptions, if unresolved, contribute to the overall pathogenesis of disease onset. This review presents the emerging role of pancreatic islet chemokine production as a critical factor regulating immune cell entry into pancreatic tissue as well as an important facilitator of changes in tissue resident leukocyte activity. Signaling through two specific chemokine receptors (i.e., CXCR2 and CXCR3) is presented to illustrate key points regarding ligand-mediated regulation of innate and adaptive immune cell responses. The prospective roles of chemokine ligands and their corresponding chemokine receptors to influence the onset and progression of autoimmune- and obesity-associated forms of diabetes are discussed.
\end{abstract}

\author{
Key Words \\ cytokine \\ - chemokine \\ - diabetes \\ - islet \\ - inflammation
}

Journal of Molecular

Endocrinology

(2017) 59, R33-R46

\section{Introduction}

Development of diabetes mellitus is currently classified based on the route by which hyperglycemia develops. Presently, type 1 diabetes (T1D) is described as an autoimmune disease that results when the function and/or mass of the insulin-producing $\beta$-cells is reduced to a degree that produces clinical symptoms (e.g., hyperglycemia, polyuria, etc.; see Atkinson et al. 2014). Type 2 diabetes (T2D) is described as a more slowly progressing disease characterized first by insulin resistance and glucose intolerance, two conditions that indicate 'pre-diabetes' (Johnson \& Olefsky 2013, Cefalu et al. 2014, Cefalu 2016). The pre-diabetes stage progresses to overt clinical onset of diabetes when the function and mass of the islet $\beta$-cells decrease to the point where the ability to maintain glucose homeostasis is ultimately lost (Kahn 1998, Doria et al. 2008, Muoio \& Newgard 2008). At present, the hallmark of each disease appears to be dysfunction of the islet $\beta$-cell population, a reduction in total numbers of insulin-producing cells or both outcomes.

While the specific subclasses of diabetes are delineated by their individual etiological associations accompanying islet $\beta$-cell death and dysfunction, there are changes in the genetic programming of $\beta$-cells during progression to each form of diabetes that contribute to and influence disease progression (Cnop et al. 2014, Donath 2014, Lopes et al. 2014, Burke \& Collier 2015, Sanchez et al. 2015). This transcriptional reprogramming is occasionally overlooked although it is an important contributor to disease progression and outcome. Precise signaling inputs control these genetic effects with the major alterations in gene transcription connected to the production of molecules that regulate cellular viability, influence immune cell recruitment, impact glucose-stimulated calcium dynamics and eventually reduce maximal glucose-mediated insulin

Published by Bioscientifica Ltd 
secretion. The end result is an overall diminution in either insulin-positive cell mass, circulating insulin levels or both. Despite distinct etiologies for T1D and T2D, understanding the pathophysiological mechanisms of each disease will likely benefit the development of therapies to treat both diseases. Thus, we begin by briefly outlining some of the noteworthy similarities between T1D and T2D to illustrate that significant parallels exist between these common endocrine diseases.

\section{Parallels between T1D and T2D}

Autoimmunity is a key driver of T1D (Castano \& Eisenbarth 1990), while obesity is one of the most important risk factors for the development of T2D (Bray 1992). However, there are a number of commonalities between T1D and T2D that are worth considering. First, insulin resistance is a risk factor for both T1D (Fourlanos et al. 2004, Donga et al. 2015) and T2D (Kahn 1998, Samuel \& Shulman 2016). Second, pro-inflammatory cytokines (e.g., IL-1 $\beta$, IFN- $\gamma$, TNF- $\alpha$, etc.) contribute to the disease phenotype in both T1D and T2D (Dogan et al. 2006, Donath 2014, Burke et al. $2015 b$ ). Third, advanced glycation end products are present in both T1D (Coughlan et al. 2011, Forbes et al. 2011) and T2D (Nowotny et al. 2015). Fourth, insulin therapy is indicated for therapeutic intervention during specific stages of each disease (Atkinson et al. 2014, Home et al. 2014, Kreider \& Lien 2015). Fifth, there are altered circulating levels of various chemokines in both T1D and T2D (Hanifi-Moghaddam et al. 2006, Shigihara et al. 2006, Takahashi et al. 2011, Sajadi et al. 2013, Corrado et al. 2014, Nunemaker et al. 2014, Burke \& Collier 2015). Sixth, there are defects in insulin secretion and calcium usage in rodent and human islets associated with T1D and T2D (Boucher et al. 2004, Dula et al. 2010, Ramadan et al. 2011, Do et al. 2014, Burke et al. 2015b, Kenty \& Melton 2015, Qureshi et al. 2015). Seventh, immune cells infiltrate the islets in both T1D and T2D (Gepts 1965, Ehses et al. 2007, Boni-Schnetzler et al. 2008, Richardson et al. 2009, Willcox et al. 2009, Burke et al. 2016). With this last point in mind, we note that excellent reviews exist discussing the immunology of diabetes (Castano \& Eisenbarth 1990, Wallberg \& Cooke 2013, Boldison \& Wong 2016). Therefore, we will focus this review around pancreatic islet $\beta$-cell chemokine production with a discussion of two important chemokine receptor-signaling paradigms that fundamentally impact specific subsets of immune cells known to participate in the pathogenesis of T1D and T2D.

\section{Chemokines: soluble secreted proteins that regulate immune cell movement and activity}

Chemotactic cytokines (aka chemokines) are a family of small $(8-10 \mathrm{kDa})$, secreted, signaling proteins that have biological impact through activation of their specific cell surface receptors. These receptor-mediated actions include the directed chemotaxis of a responsive target cell, changes in intracellular second messengers, and the ability to influence gene expression, protein localization, protein production and secretion of molecules relevant to immune cell function (Charo \& Ransohoff 2006). Chemokines are currently classified by their structural characteristics and are divided into different families based on the spacing of their N-terminal cysteines (i.e., CC, $\mathrm{CXC}, \mathrm{CX}_{3} \mathrm{C}$ or $\mathrm{C}$ ). Chemokines as a group are usually sub-classified into homeostatic or pro-inflammatory categories, with many present in both groups. These proteins direct leukocyte migration and influence immune cell activity. Their contribution to development, onset, maintenance and resolution of various disease processes constitute active research areas.

Chemokines are protein ligands for their cognate chemokine receptors, which are members of the much larger G protein coupled receptor (GPCR) superfamily. Upon ligand binding to the chemokine receptor, a conformational change leads to the exchange of GDP with GTP and the activation of the heterotrimeric G proteins (Pierce et al. 2002). These heterotrimeric G proteins consist of 21,6 and 12 different $G \alpha, \beta$ and $\gamma$ subunits, respectively, which contribute to the complexity of signaling outputs. The downstream effects of GPCR activation is dictated by signal strength and subsequent effects on the receptors: internalization (Marchese et al. 2008), intracellular location (Jiao et al. 2005), hetero/ homo-dimerization (Trettel et al. 2003, Wilson et al. 2005, Martinez Munoz et al. 2009) and G protein subunit usage (Khan et al. 2013, Syrovatkina et al. 2016). In addition, the desensitization and inactivation of the intracellular signal also affects signaling outcomes. $G$ protein receptor kinases (GRKs) and $\beta$-arrestins turn off the signaling of individual chemokine receptors.

Interestingly, $\beta$-arrestins can also induce their own downstream signaling outcomes (Luttrell \& Lefkowitz 2002, Shenoy \& Lefkowitz 2005, Defea 2008), with the levels of the desensitizing proteins and their isoforms affecting the overall signaling mechanisms. For example, CXCR1 and CXCR2 bind to GRK2 and GRK6, respectively, which produce differences in neutrophil http://jme.endocrinology-journals.org DOI: 10.1530/JME-17-0042
() 2017 Society for Endocrinology Printed in Great Britain
Published by Bioscientifica Ltd 
activation (Raghuwanshi et al. 2012). Discrete activation mechanisms allow for fine-tuning of the chemokine signaling pathways, an important observation bearing in mind there are $\sim 50$ associated chemokine ligands that impact 20 different chemokine receptors. Most of the chemokine receptors display promiscuous interaction with multiple chemokines, which was initially thought as redundancy in the biological setting. However, in light of recent data on chemokine receptor activation linked to specific biological responses, a more complex picture has formed showing multiple different stimuli at the same receptor trigger differential downstream effects (Zweemer et al. 2014). In other words, one receptor can produce distinct outcomes depending on which ligand occupies the binding site. This updated paradigm is often referred to as biased signaling, biased agonism or functional selectivity (Wisler et al. 2014, Karin et al. 2016).

In the case of both $\mathrm{T} 1 \mathrm{D}$ and $\mathrm{T} 2 \mathrm{D}$, we postulate that the most logical biochemical and immunological explanation for the initial and sustained entry of one or more immune cell populations into pancreatic tissue is directed chemotaxis by specific signaling molecules (e.g., chemokines). Because increased immune cell presence within pancreatic tissue occurs as part of the phenotype underlying T1D and T2D (Foulis \& Stewart 1984, Foulis et al. 1991, Boni-Schnetzler et al. 2008, Donath et al. 2008, Hanafusa \& Imagawa 2008), we and others have focused a significant portion of our research efforts into understanding the inflammation-associated processes related to islet chemokine production and secretion. Below, we provide a brief discussion of signaling through two representative chemokine receptors relevant to innate and adaptive immunity.

\section{Chemokine ligand activation of chemokine receptors in innate and adaptive immunity}

Pancreatic $\beta$-cells synthesize and secrete a variety of chemokines capable of recruiting leukocytes into pancreatic tissue (Sarkar et al. 2012). The expression of many of these chemokines is markedly enhanced by $\beta$-cell exposure to inflammatory signals (Sarkar et al. 2012, Cnop et al. 2014, Lopes et al. 2014, Burke \& Collier 2015). Below, we focus on ligand-mediated signaling events associated with CXCR2 and CXCR3, which are two specific chemokine receptors reported to influence onset and progression of diabetes. These two receptors are also important because they exemplify enriched expression in neutrophils (CXCR2) and T-cells (CXCR3). Because $\beta$-cell exposure to inflammatory mediators induces various chemokine ligands that bind to CXCR2 and CXCR3 (Burke et al. 2014, 2015a,b, 2016), we discuss what is known about the activation pathways of these two receptors and the downstream effector mechanisms that contribute to immune activation and subsequent $\beta$-cell destruction.

\section{CXCR2}

CXCR2 is highly expressed on neutrophils (Murphy \& Tiffany 1991, Liu et al. 2010) and oligodendrocytes (Veenstra \& Ransohoff 2012). It is expressed less consistently on T cells, basophils, mast cells and epithelial cells during wound healing. CXCR2 binds ELR-CXC chemokines (CXCL1, CXCL2, CXCL3, CXCL5, CXCL6, CXCL7 and CXCL8) with high affinity. CXCR1 binds CXCL8 with high affinity, while CXCL6 and CXCL7 bind less well to CXCR1 than to CXCR2 (Waugh \& Wilson 2008). In the case of CXCR2, this biased agonism (or functional selectivity) was initially thought of as redundancy for receptor activation. However, distinct and complex signaling crosstalk produces different phenotypic responses and is now thought to be important for physiological and pathophysiological outcomes (Zweemer et al. 2014).

For CXCR2 activation, specific chemokines bind and activate the receptor via the amino terminus and first extracellular loop. Site directed mutagenesis in these regions generates different activation and functional consequences (Katancik et al. 1997, Katancik et al. 2000). The receptor-associated signal is transduced to the second intracellular loop where the G proteins are bound to the aspartic acid, arginine and tyrosine (DRY) box and leads to the GDP to GTP exchange and G protein activation. After activation the carboxyl terminus is phosphorylated on the LLKIL motif, which leads to activation of the $\beta$-arrestins and internalization/desensitization (Raman et al. 2014). The receptor is then targeted to different endosomal compartments based on its phosphorylation state for degradation or recycling. These varied signals from CXCR2 stimulation initiate intracellular $\mathrm{Ca}^{++}$flux, inhibition of apoptosis, migration, priming and adhesion depending on the downstream signaling pathway that is activated (Mocsai 2013). Neutrophil recruitment via CXCR2 is critical for the autoimmune responses targeting islet $\beta$-cells; inhibiting CXCR2 partially blocks this outcome (Citro et al. 2012, Diana \& Lehuen 2014).

Moreover, neutrophils and CXCR2 signaling during diabetes development were shown in the NOD mouse model, which develops T1D spontaneously with many

Published by Bioscientifica Ltd. 
features of the human disease. When CXCR2 was inhibited or neutrophils were depleted, disease progression was limited in these mice (Diana et al. 2013, Citro et al. 2015). Additional evidence showing that allosteric inhibitors of CXCR2/CXCR1 lead to prolonged survival of islet transplants in both mice and humans confirms the importance of neutrophil chemokine/chemokine receptor activation during disease onset (Citro et al. 2012). Using neutrophil elastase inhibitors, Talukdar et al. demonstrated that neutrophils also impact obesity-induced insulin resistance (Talukdar et al. 2012). Taken together, these data illustrate the promise of CXCR2- and/or neutrophil-based immunomodulatory strategies as possible treatments for pathological responses that contribute to the onset of T1D and T2D.

\section{CXCR3}

The interferon (IFN)-inducible, non-ELR CXC chemokine subgroup includes CXCL9 (Mig), CXCL10 (IP10) and CXCL11 (I-TAC), which are proteins that bind to CXCR3 (Groom \& Luster 2011). This receptor is mainly found on NK cells and $\mathrm{T}$ cells and has a role in a variety of diseases, especially those with a Th component (Van Raemdonck et al. 2015). When CXCL10 is expressed in the islets of transgenic mice, an accelerated autoreactive immunological response was observed (Rhode et al. 2005). In addition, islet isografts were protected when CXCL10 expression was diminished (Bender et al. 2017). Serum CXCL10 levels are increased in both human subjects and in the NOD mouse model, linking elevated chemokine production with diabetes (Christen et al. 2003, Antonelli et al. 2014, Corrado et al. 2014). When CXCR3 is knocked out, there is a delay in the onset of virally induced diabetes (Frigerio et al. 2002) and in diabetes induced by multiple low doses of streptozotocin (Burke et al. 2016). By contrast, when CXCR3 null mice are crossed onto the NOD background, T1D development is accelerated (Yamada et al. 2012). What appear to be contrary findings could be due to genetic differences in the different mouse strains, the distinct models of T1D or functional selectivity of CXCR3 activation that is related to strain and/or the models of diabetes.

It is important to note that mice on a C57BL/6 background do not produce CXCL11 due to an insertion of 2 bases after nucleotide 39 , which shifts the open reading frame of the CXCL11-encoding gene to a premature stop codon (Sierro et al. 2007). By contrast, the NOD mice retain the ability to produce CXCL11, which could explain differences in whole body phenotypes observed between knockouts of CXCR3 when compared with C57BL/6 mice. In the viral model of T1D, knocking out ligands binding to CXCR3 showed redundancy instead of biased agonism, i.e., knocking out one of the CXCR3 ligands had no effect (Coppieters et al. 2013), leaving us to speculate how the individual ligands contribute to onset and progression of diabetes. Along these lines, the different chemokine ligands that bind CXCR3 show biased agonism during in vitro studies. Watts and coworkers used impedance measurements, BRET and CRE luciferase assays to show that CXCL9 induces $\beta$-arrestin binding and produces higher impedance measurements when compared with CXCL10 and CXCL11 (Watts et al. 2012). Conversely, Rajagopal and coworkers showed bias only for CXCR3 for internalization, with CXCL11 the more potent agonist when compared with CXCL9 and CXCL10 (Rajagopal 2013, Rajagopal et al. 2013). Although the signaling pathways activated after differential ligand binding have not been fully elucidated, there are some clues about CXCR3 signal transduction cascades that are informative. For example, the differential downstream signaling is due, at least in part, to differential $G \alpha$ subunit usage (Kouroumalis et al. 2005, Thompson et al. 2007). CXCL10 stimulation of CXCR3 also leads to activation of the ERK/Ras pathway and an increase in migration and signaling (Bonacchi et al. 2001).

Decoding the chemokine receptor signaling pathways could allow for drugs that have functional selectivity for some of the beneficial phenotypes while ideally eliminating the detrimental outcomes. One clue to the importance of specific pathways on diabetes development came from nucleotide-binding leucine-rich repeat and pyrin domaincontaining protein 3 (NLRP3) knockout mice; NLRP3 functions as part of the innate immune system via pattern recognition responses (Martinon 2008). In NLRP3-/- mice, expression of CXCR3, and the corresponding ligands, CXCL9 and CXCL10, were decreased (Hu et al. 2015). The expression of other chemokines and their receptors was also reduced. Importantly, diabetes took longer to develop in NLRP3-/- mice, implying that these chemokines and associated receptors contribute to T1D development.

On a related note, the small molecule CXCR3 antagonist, SCH 546738, was shown to prevent autoimmune diseases (Jenh et al. 2012), while another CXCR3 inhibitor, NBI-74330, had distinct potencies for the different CXCR3 ligands (Heise et al. 2005). Whether this information regarding functional selectivity will be useful for the design of new therapeutics aimed at modulating human CXCR3 pathways during autoimmune diseases remains to be revealed. It will be of particular interest to

Published by Bioscientifica Ltd 
determine whether any of the existing molecules targeting chemokine receptors directly have therapeutic benefit in the different models of diabetes.

\section{Islet-derived chemokines in T1D}

Genes encoding chemokines are located within the known diabetes susceptibility locus Idd4 in the NOD mouse, which is associated with T1D development (Grattan et al. 2002). While the initial trigger(s) prompting the onset of $\beta$-cell directed autoimmunity is unknown, enhanced production and release of chemokines from pancreatic islets coupled with the associated chemokine receptor activation on individual leukocytes is a very plausible component of the disease course. The following components are proposed to be contributors to T1D development: (1) secretion of cytokines and chemokines by resident immune cells (e.g., macrophages) in response to a specific pathogen or pathogenic signal (e.g., death of surrounding cells, viral infection, LPS, etc.); (2) the production of isletderived chemokines increases in response to such signals, promoting the recruitment of additional immune cell populations (e.g, neutrophils, T-cells, etc.) into the pancreatic islets; (3) T-cell priming for one or more antigens (typically $\beta$-cell specific); (4) chemokine-mediated entry of primed lymphocytes into the pancreatic tissue; (5) continued production and release of cytokines (e.g., IL-1 $\beta$, IFN- $\gamma$, etc.) that regulate inflammatory responses, including immune cell activity, within pancreatic islets; and (6) sustained production of chemokines, including from pancreatic $\beta$-cells, creating a vicious feed forward cycle intended to either clear infection or promote tissue repair (physiological outcome) that transitions during chronic disease states (e.g., autoimmunity) to become pathophysiological. Portions of this model have been validated using transgenic mouse models where production of CCL2 or CXCL10 directly from $\beta$-cells stimulates immune cell entry into the pancreatic tissue (Grewal et al. 1997, Rhode et al. 2005, Martin et al. 2008b) and by reducing chemokine action via decoy receptor expression in NOD mice (Martin et al. 2008a).
T1D arises through multiple immune cell interactions, including macrophages, neutrophils and T-cells (Calderon et al. 2006, Diana et al. 2013). This means various innate and adaptive immune cells, and molecules secreted from such cells, all participate and contribute in some capacity to the disease pathology. Thus, signals contributing to immune cell recruitment, such as chemokines, are critical players in initiating, accelerating and/or maintaining disease trajectory. Consistent with this idea, IL- $1 \alpha$ and TNF- $\alpha$ are elevated in 'at risk' and new onset T1D subjects when compared with healthy controls (Rosa et al. 2008, Chatzigeorgiou et al. 2010, Zak et al. 2010). IL-1 $\alpha$ and TNF- $\alpha$ signal through the IL-1 receptor and TNF receptor, respectively, both of which activate the NF-kB pathway. NF-kB activation drives production of multiple chemokines in islet $\beta$-cells (Burke \& Collier 2014, 2015) and reduces insulin secretion in rodent and human islets (Giannoukakis et al. 2000, Rehman et al. 2003, Rink et al. 2012, Burke et al. 2015b). Conversely, restricting NF- $\mathrm{kB}$ activity in the multiple low dose streptozotocin (MLDS) model reduces chemokine production and protects against hyperglycemia (Eldor et al. 2006). In an alternative approach, blocking chemokine action using decoy receptors also revealed key roles for chemokine proteins in the pathogenesis of diabetes development (Martin et al. 2007, 2008a).

When examining rodent models of T1D (Tables 1 and 2), the production and release of CXCL9 and CXCL10 protein in islets from 4 and 10-weekold NOD mice correlated with the degree of insulitis (Welzen-Coppens et al. 2013). Blocking CXCL10 activity with neutralizing antibodies prevented re-infiltration of pancreatic islets after a course of anti-CD3 therapy (Lasch et al.2015). Because T-cells primed with autoantigens typically produce and secrete IFN- $\gamma$, targeted upregulation of CXCL10 by IFN- $\gamma$ signaling in $\beta$-cells is likely contributing to T1D disease pathology (Burke et al. 2013a, 2016, Lundberg et al. 2016). The enhanced transcription of the CXCL10 gene is also consistent with heightened STAT1 activity in islet $\beta$-cells (Burke et al. 2013a, Lundberg et al. 2016). Moreover, pro-inflammatory cytokines (e.g., IL-1 $\beta$,

Table 1 Islet chemokines in monogenic rodent models of obesity and diabetes.

\begin{tabular}{l} 
Animal model (species) \\
\hline Akita (mouse) \\
$d b / d b$ (mouse) \\
KKAy (mouse) \\
ZDF (rat)
\end{tabular}

\begin{tabular}{l} 
Relevant human condition \\
\hline ER stress/insulin insufficiency \\
Obesity/T2D \\
Obesity/T2D \\
Obesity/T2D
\end{tabular}

\begin{tabular}{l} 
Islet chemokine production \\
\hline Noa \\
Yes \\
Yes \\
Yes
\end{tabular}

\begin{tabular}{l} 
References \\
\hline Burke SJ (unpublished observations)b \\
Eguchi et al. (2012), Burke et al. (2015a) \\
Eguchi et al. (2012) \\
Jourdan et al. (2013)
\end{tabular}

aMale mice at 8 weeks of age.

bSJ Burke, MD Karlstad \& JJ Collier, unpublished observations.

http://jme.endocrinology-journals.org DOI: 10.1530/JME-17-0042
() 2017 Society for Endocrinology Printed in Great Britain
Published by Bioscientifica Ltd 
Table 2 Islet chemokines in polygenic rodent models of obesity and diabetes.

\begin{tabular}{l} 
Animal model (species) \\
\hline BB (rat) \\
GK (rat) \\
MLDS (mouse/rat)* \\
NOD (mouse)
\end{tabular}

\begin{tabular}{l} 
Relevant human condition \\
\hline Autoimmunity/T1D \\
Insulin resistance/T2D \\
Insulin insufficiency/T1D \\
Autoimmunity/T1D
\end{tabular}

\begin{tabular}{l} 
Islet chemokine production \\
\hline Yes \\
Yes \\
Yes \\
Yes \\
\hline
\end{tabular}

*MLDS, multiple low doses of streptozotocin (STZ). STZ impacts multiple mouse and rat strains; thus, we have included it under the polygenic models.

IFN- $\gamma$, etc.) increase the expression of CXCL9 and CXCL11 in mouse, rat, and human $\beta$-cells using activated STAT1 as a key component of the signaling response (Burke et al. 2016). STAT1 is therefore a key driver of chemokine production (Burke et al. 2013a, 2016) and inducible nitric oxide synthase abundance and activity (Burke et al. 2013b, 2015b, Corbett et al. 1992, 1993, Heitmeier et al. 1997). Increased STAT1 expression is also strongly correlated with HLA class I (i.e. HLA-ABC) and HLA-F isoforms in insulincontaining islets (Richardson et al. 2016). Thus, NF-кB and STAT1 likely cooperate to control inflammatory responses within pancreatic islets, which ultimately determine the autoimmune and auto-inflammatory outcomes (Fig. 1). The model shown in Fig. 1 offers an attractive conceptual framework from which to explain why individual immunomodulatory approaches may have underachieved from a therapeutic perspective.

One such example of a promising single immunomodulatory strategy that has thus far failed to produce remission, or prevent T1D, in mice is anti-IL-1 $\beta$ neutralization (Gill et al. 2015). Although it was promising that human subjects with recent onset T1D receiving a targeted anti-IL-1 therapeutic (Anakinra) displayed reduced insulin requirements one and four months after diagnosis compared to controls (Sumpter et al. 2011), in a larger study, IL-1 neutralization strategies were not effective at meeting the clinical endpoints (Moran et al. 2013). It is worth noting, however, that one month after diagnosis the insulin-dose-adjusted A1c in patients given Anakinra was lower than controls (Sumpter et al. 2011).

Multiple explanations might exist to explain these initially disappointing findings. The first is that the neutralization or trap strategies do not completely block signaling through the IL-1 receptor, which has two known agonist ligands (i.e., IL- $1 \alpha$ and IL-1 $\beta$ ). The second explanation is that other signals, such as TNF- $\alpha$ or ligands that activate pattern recognition receptors (PRR), can still activate NF- $\mathrm{B}$ despite interventions that restrict signaling through the IL-1 receptor (Fig. 1). The third explanation is that signaling through specific receptors, such as IL-1R1, may have both physiological and pathological outcomes and that receptor antagonism eliminates both positive and negative outcomes.

We note that NF-кB activation by a variety of inflammatory pathways, in conjunction with elevated levels of STAT1 and/or enhanced STAT1 transcriptional responses, would likely support sustained production of soluble factors (e.g., chemokines) that influence immune cell recruitment. In addition, the powerful combination of NF- $\mathrm{kB}$ and STAT1 activation regulates other key genes

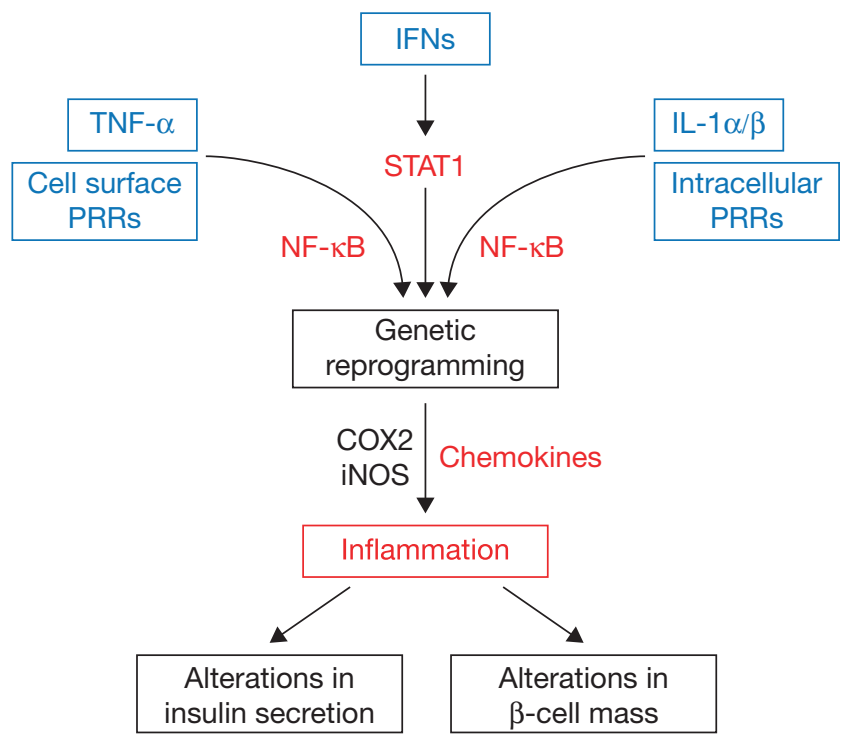

Figure 1

Signals that activate NF- $\mathrm{kB}$ and STAT1 enhance chemokine production within pancreatic islets that contribute to the inflammatory response influencing both insulin secretion and total $\beta$-cell mass. Many signals converge on the NF- $\mathrm{KB}$ and STAT1 pathways to coordinately reprogram beta cells at a transcriptional level, leading to inflammation-based changes in insulin secretion, $\beta$-cell mass or both. PRRs can be either cell surface based, such as Toll-like receptor-2 and -4 or positioned intracellularly (e.g., Toll-like receptor-3, NOD1, NOD2, etc.). TNF- $\alpha$ and IL-1 signal through specific cell surface receptors (receptor not shown) and converge on the NF-кB pathway. The interferon family of cytokines signals through cell surface receptors that activate JAK-STAT pathways. Activation of COX2 produces prostaglandins, which may influence leukocyte activity. Cytokine-mediated increases in iNOS elevate intracellular production of nitric oxide, which acts as a rheostat for insulin secretion. COX2, cyclooxygenase-2; IFNs, interferons alpha, beta and gamma; iNOS, inducible nitric oxide synthase; PRR, pattern recognition receptors.

Published by Bioscientifica Ltd. 
relevant to islet $\beta$-cell function and dysfunction (Fig. 1). Consequently, in our view, combination therapies may end up providing the most benefit to prevention of autoimmune diseases, such as T1D, by restricting signaling of multiple pathways that collectively contribute to chemokine production, and other important mediators of inflammation, which ultimately regulate islet $\beta$-cell function and mass.

\section{Islet-derived chemokines in T2D}

Multiple models of rodent obesity and diabetes display elevations in islet chemokine production (Tables 1 and 2). In addition, staining of human pancreatic tissue revealed high levels of CXCL10 in islets from subjects with T2D (Schulthess et al. 2009) while RNA sequencing approaches showed the expression of multiple chemokines in human islets exposed to the fatty acid palmitate (Cnop et al. 2014). These data are consistent with enhanced leukocyte presence in human pancreatic tissue during obesity (Boni-Schnetzler et al. 2008, Donath et al. 2008). Schulthess and coworkers suggest that CXCL10 signals through TLR4 on $\beta$-cells as a mechanism for deleterious effects during obesity (Schulthess et al. 2009). While an intriguing possibility, these observations still await independent verification.

On the other hand, genetic deletion of the $\mathrm{CX}_{3} \mathrm{CR} 1$ receptor reduces insulin secretion in response to the physiological signals glucose and GLP-1 (Lee et al. 2013). The chemokine $\mathrm{CX}_{3} \mathrm{CL} 1$ (aka fractalkine), which signals through $\mathrm{CX}_{3} \mathrm{CR} 1$, is decreased in islets during aging and obesity (Lee et al. 2013). It is therefore possible that particular chemokines promote $\beta$-cell health, either by recruiting specific immune cells, through direct effects on $\beta$-cells, or both. In addition to mechanisms that support leukocyte recruitment and production of pro-inflammatory cytokines, loss of these 'protective' or homeostatic chemokines might be a mechanism which also contributes to $\beta$-cell dysfunction during progression to T2D.

\section{Obesity and islet inflammation}

How does obesity trigger islet inflammation? Since no one mechanism has emerged to explain all observations, we put forth two conceptual possibilities. The first is that obesity negatively influences gut barrier function, allowing translocation of bacterial products initially into the mesenteric lymphatic system and then into the systemic circulation (Fig. 2A). This elevation in lipopolysaccharide (LPS), or other molecules that signal through pattern recognition receptors, may contribute to the subclinical, low grade inflammation that drives insulin resistance and associated tissue dysfunction (Carneiro et al. 2008, Purohit et al. 2013, Cox et al. 2015). With this in mind, it is conceivable that islet resident macrophages become activated during obesity due to elevated levels of circulating LPS derived from increased intestinal permeability (i.e., 'leaky gut'). The presence of LPS increases macrophage cytokine production and also enhances macrophage sensitivity to IFN- $\gamma$ (Held et al. 1999).

IFN- $\gamma$ is a cytokine that activates macrophages and also promotes the differentiation of immature DCs into effector DCs that heavily influence Th1 responses (Boehm et al. 1997). These biological responses are intended to induce robust anti-bacterial activity, but may be dysregulated during obesity. Indeed, CXCL8, CXCL10 and IFN- $\gamma$ increase in circulation with excess body weight (Straczkowski et al. 2002, Sharabiani et al. 2011). Consequently, it is plausible that bacterial translocation from a leaky gut results in a low level of LPS that, in combination with elevations in other circulating factors linked with inflammation, promotes detrimental changes in pancreatic islets. Macrophage cytokine production is a key component that impacts pancreatic islet function and mass (Fig. 2A). While speculative, this mechanism fits with existing observations put forth in the literature (Balzan et al. 2007, Cani \& Delzenne 2007, Cani et al. 2007).

The second conceptual possibility explaining how obesity leads to islet inflammation is lipid overload and associated metabolic trauma (Fig. 2B). In this model, lipids accumulate in lean tissues once storage in adipose tissue has been exceeded (Unger \& Orci 2000, Unger 2003). Lean tissue responses to surplus fatty acids may vary. For example, fatty acids promote macrophage activation as well as chemokine production in pancreatic islets (Eguchi et al. 2012), potentially via cell surface (e.g., TLR4) or intracellular (e.g., NOD1, NOD2, etc.) pattern recognition receptor signaling (Fig. 1). Moreover, incomplete fatty acid oxidation products drive enhanced NF- $\mathrm{KB}$ activity in macrophages, promoting proinflammatory actions (Rutkowsky et al. 2014). If such incomplete fatty acid oxidation mechanisms also occur in $\beta$-cells, it could help to explain lipid-induced changes in $\beta$-cell insulin secretion as well as chemokine production that occur in obesity (Burke et al. 2015b, Eguchi et al. 2009, http://jme.endocrinology-journals.org DOI: 10.1530/JME-17-0042
() 2017 Society for Endocrinology Printed in Great Britain
Published by Bioscientifica Ltd 
A

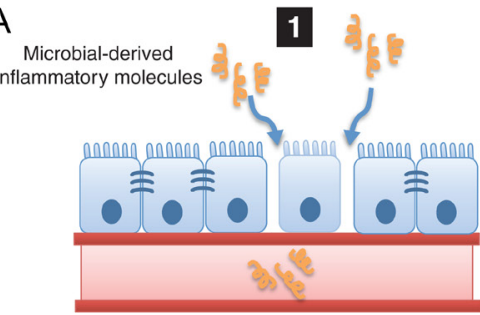

Circulation

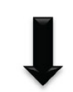

Innate Immune Cells

Adaptive Immune Cells

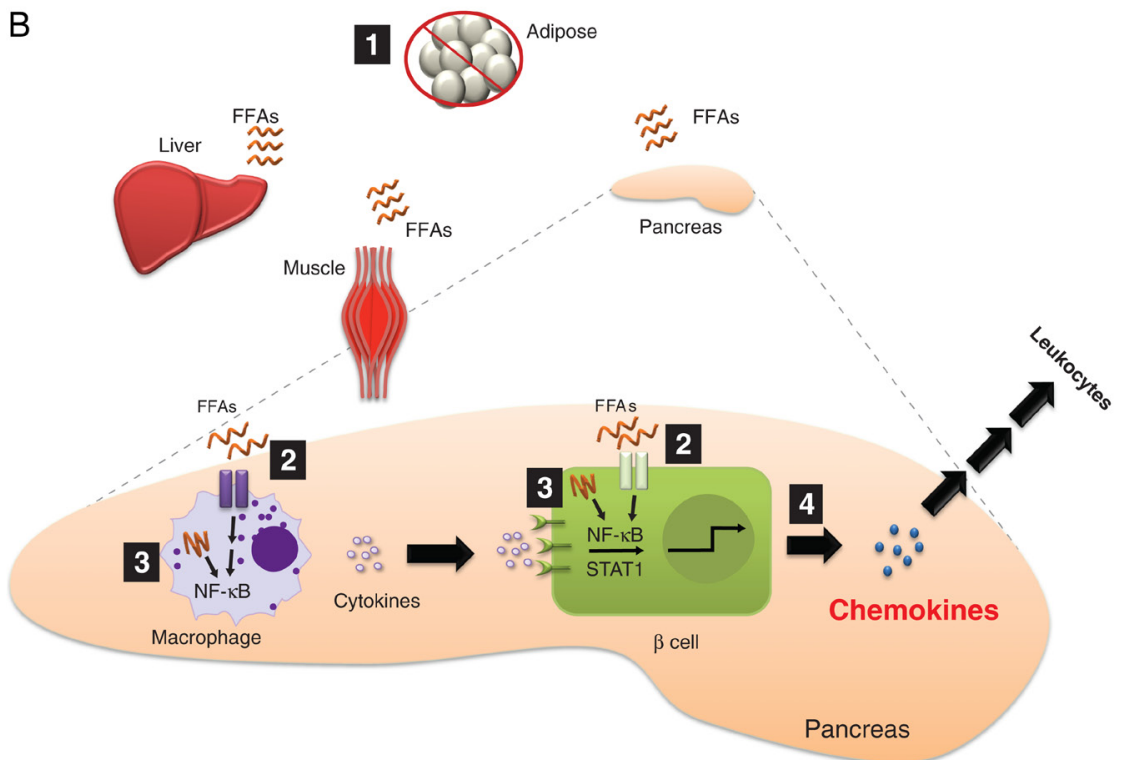

Figure 2

Conceptual models for how obesity may influence islet inflammation and chemokine production. (A) 1. Increased intestinal permeability allows microbial products (e.g., LPS) to enter the circulation. 2. These molecules are 'sensed' by pattern recognition receptor enriched in immune cells, such as neutrophils (not shown) and macrophages (shown). An increase in macrophage activation leads to production and release of cytokines (e.g., IL-1 $\beta$ ). 3. Distinct pro-inflammatory cytokines (e.g., IL-1 $\beta$, IFN- $\gamma_{\text {, }}$ TNF- $\alpha$, etc.) promote transcriptionally active NF- $\kappa B$ and STAT1 proteins. 4. The NF-кB and STAT1 pathways regulate chemokine production in betacells; release of $\beta$-cell derived chemokines influences innate and adaptive immune responses. (B) 1. When consumption of free fatty acids (FFAs) exceeds storage capacity in adipose tissue, these lipids begin to be stored in lean tissues (e.g. liver, muscle and pancreas). 2. FFAs activate cell surface receptors, altering intracellular signaling pathways. 3. Incomplete fatty acid oxidation may also activate signaling pathways, such as NF- $\mathrm{kB}$, that are linked with transcriptional changes. 4. Chemokine production is elevated in the obese, insulin resistant state, which would impact both tissue resident and infiltrating leukocytes.
2012). This is important because the increase in $\beta$-cell chemokine production by inflammatory signals coincides with diminutions in insulin secretion (Burke et al. 2015b).

Moreover, accumulation of excess lipid within $\beta$-cells impairs insulin secretion, at least in part, by interfering with metabolic coupling steps, such as pyruvate cycling (Boucher et al. 2004). Reducing the lipid burden or restoring pyruvate cycling improves islet $\beta$-cell secretory function (Shimabukuro et al. 1998, Boucher et al. 2004). Finally, intracellular lipid accumulation in the islet $\beta$-cell may also result in ER stress. Induction of mild ER stress induces $\beta$-cell proliferation (Sharma et al. 2015), while lipid signaling through pattern recognition receptors likely reduces $\beta$-cell function and promotes production of molecules, such as chemokines and cytokines, that modulate immune cell recruitment and inflammation (Boni-Schnetzler et al. 2009).

Thus, multiple signaling mechanisms may exist to limit insulin secretion while augmenting chemokine production within pancreatic islets (and other tissues), driving increased immune cell infiltration and therefore influencing the status of pancreatic inflammation. Because increased numbers of immune cells have been observed within pancreatic islets from both rodents and humans during obesity validate these findings as conserved, important phenotypes (Ehses et al. 2007, 
Boni-Schnetzler et al. 2008, Donath et al. 2008). However, it is important to note that any immune cell entry into the pancreatic tissue is often heterogeneous. In addition, changes in the tissue resident immune cell activation state (e.g., M2 $\rightarrow$ M1), without enhancements in immune cell number, could also drive inflammation-mediated changes in tissue function (Burke \& Collier 2014).

Consistent with changes in leukocyte number or activation state, increased presence of chemokine ligands has been documented in pancreatic islets of mice, rats and humans during obesity (Donath et al. 2008, Schulthess et al. 2009, Eguchi et al. 2012, Sajadi et al. 2013, Burke et al. 2015a). While there is no doubt that obesity is a major risk factor for the development of T2D, the molecular determinants explaining the increased risk are still being investigated. Our view is that pancreatic islet-derived chemokines play critical roles by regulating immune cell flux into the pancreatic islets, influencing the activation state of resident immune cells or both. These outcomes ultimately impact $\beta$-cell substrate metabolism linked with insulin secretion as well as influencing proliferation of insulin-producing cells.

\section{Summary and conclusion}

A role for elevated chemokine production within $\beta$-cells as a critical mechanistic determinant controlling islet inflammation during T1D and T2D development is emerging (Tables 1 and 2). Chemokines, and other proteins that regulate inflammation, can be induced by a variety of signals that activate either STAT1, NF- $\mathrm{kB}$ or both signaling pathways (Fig. 1). The increased synthesis and secretion of discrete chemokines induce receptormediated signals that regulate immune cell entry into, and activity within, pancreatic tissue (Fig. 2). Importantly, chemokine production in pancreatic islets appears to be a common phenomenon between T1D and T2D. While rodent work has been incredibly informative towards understanding the genetics and phenotypes of the human disease, much remains to be uncovered. It is our hope that understanding the inflammatory signaling-induced upregulation of chemokine production and chemokine/ chemokine receptor interactions will assist in the design of therapeutics relevant to improving $\beta$-cell mass and secretory function as a way to combat the growing incidence of T1D and T2D.

\section{Declaration of interest}

The authors declare that there is no conflict of interest that could be perceived as prejudicing the impartiality of this review.

\section{Funding}

Work in the authors' laboratories was supported by NIH grants P20 GM103528 (J J C), P30 GM118430 (J J C), R44 GM099207 (J J C and M D K) and R01 Al071042 (T E S).

\section{References}

Antonelli A, Ferrari SM, Corrado A, Ferrannini E \& Fallahi P 2014 CXCR3, CXCL10 and type 1 diabetes. Cytokine and Growth Factor Reviews 25 57-65. (doi:10.1016/j.cytogfr.2014.01.006)

Atkinson MA, Eisenbarth GS \& Michels AW 2014 Type 1 diabetes. Lancet 383 69-82. (doi:10.1016/S0140-6736(13)60591-7)

Balzan S, de Almeida Quadros C, de Cleva R, Zilberstein B \& Cecconello I 2007 Bacterial translocation: overview of mechanisms and clinical impact. Journal of Gastroenterology and Hepatology 22 464-471. (doi:10.1111/j.1440-1746.2007.04933.x)

Bender C, Christen S, Scholich K, Bayer M, Pfeilschifter JM, Hintermann E \& Christen U 2017 Islet-expressed CXCL10 promotes autoimmune destruction of islet isografts in mice with type 1 diabetes. Diabetes 66 113-126. (doi:10.2337/db16-0547)

Boehm U, Klamp T, Groot M \& Howard JC 1997 Cellular responses to interferon-gamma. Annual Review of Immunology 15 749-795. (doi:10.1146/annurev.immunol.15.1.749)

Boldison J \& Wong FS 2016 Immune and pancreatic beta cell interactions in type 1 diabetes. Trends in Endocrinology and Metabolism 27 856-867. (doi:10.1016/j.tem.2016.08.007)

Bonacchi A, Romagnani P, Romanelli RG, Efsen E, Annunziato F, Lasagni L, Francalanci M, Serio M, Laffi G, Pinzani M, et al. 2001 Signal transduction by the chemokine receptor CXCR3: activation of Ras/ ERK, Src, and phosphatidylinositol 3-kinase/Akt controls cell migration and proliferation in human vascular pericytes. Journal of Biological Chemistry 276 9945-9954. (doi:10.1074/jbc.M010303200)

Boni-Schnetzler M, Ehses JA, Faulenbach M \& Donath MY 2008 Insulitis in type 2 diabetes. Diabetes, Obesity and Metabolism 10 (Supplement 4) 201-204. (doi:10.1111/j.1463-1326.2008.00950.x)

Boni-Schnetzler M, Boller S, Debray S, Bouzakri K, Meier DT, Prazak R, Kerr-Conte J, Pattou F, Ehses JA, Schuit FC, et al. 2009 Free fatty acids induce a proinflammatory response in islets via the abundantly expressed interleukin-1 receptor I. Endocrinology 150 5218-5229. (doi:10.1210/en.2009-0543)

Boucher A, Lu D, Burgess SC, Telemaque-Potts S, Jensen MV, Mulder H, Wang MY, Unger RH, Sherry AD \& Newgard CB 2004 Biochemical mechanism of lipid-induced impairment of glucose-stimulated insulin secretion and reversal with a malate analogue. Journal of Biological Chemistry 279 27263-27271. (doi:10.1074/jbc. M401167200)

Bray GA 1992 Obesity increases risk for diabetes. International Journal of Obesity and Related Metabolic Disorders 16 (Supplement 4) S13-S17.

Burke SJ \& Collier JJ 2014 Insulitis and diabetes: a perspective on islet inflammation. Immunome Research 11 (S2) e002. (doi:10.4172/17457580.S2.e002)

Burke SJ \& Collier JJ 2015 Transcriptional regulation of chemokine genes: a link to pancreatic islet inflammation? Biomolecules 5 1020-1034. (doi:10.3390/biom5021020)

Burke SJ, Goff MR, Lu D, Proud D, Karlstad MD \& Collier JJ $2013 a$ Synergistic expression of the CXCL10 gene in response to IL-1beta and IFN-gamma involves NF-kappaB, phosphorylation of STAT1 at Tyr701, and acetylation of histones H3 and H4. Journal of Immunology 191 323-336. (doi:10.4049/jimmunol.1300344)

Burke SJ, Updegraff BL, Bellich RM, Goff MR, Lu D, Minkin SC Jr, Karlstad MD \& Collier JJ 2013b Regulation of iNOS gene transcription by IL-1beta and IFN-gamma requires a coactivator exchange mechanism. Molecular Endocrinology 27 1724-1742. (doi:10.1210/me.2013-1159)

Published by Bioscientifica Ltd. 
Burke SJ, Lu D, Sparer TE, Masi T, Goff MR, Karlstad MD \& Collier JJ 2014 NF-kappaB and STAT1 control CXCL1 and CXCL2 gene transcription. American Journal of Physiology: Endocrinology and Metabolism 306 E131-E149. (doi:10.1152/ajpendo.00347.2013)

Burke SJ, Karlstad MD, Regal KM, Sparer TE, Lu D, Elks CM, Grant RW, Stephens JM, Burk DH \& Collier JJ 2015a CCL20 is elevated during obesity and differentially regulated by NF-kappaB subunits in pancreatic beta-cells. Biochimica et Biophysica Acta 1849 637-652. (doi:10.1016/j.bbagrm.2015.03.007)

Burke SJ, Stadler K, Lu D, Gleason E, Han A, Donohoe DR, Rogers RC, Hermann GE, Karlstad MD \& Collier JJ 2015 $b$ IL-1beta reciprocally regulates chemokine and insulin secretion in pancreatic beta-cells via NF-kappaB. American Journal of Physiology: Endocrinology and Metabolism 309 E715-E726. (doi:10.1152/ajpendo.00153.2015)

Burke SJ, Karlstad MD, Eder AE, Regal KM, Lu D, Burk DH \& Collier JJ 2016 Pancreatic beta-Cell production of CXCR3 ligands precedes diabetes onset. Biofactors 42 703-715. (doi:10.1002/biof.1304)

Calderon B, Suri A \& Unanue ER 2006 In CD4+ T-cell-induced diabetes, macrophages are the final effector cells that mediate islet beta-cell killing: studies from an acute model. American Journal of Pathology 169 2137-2147. (doi:10.2353/ajpath.2006.060539)

Cani PD \& Delzenne NM 2007 Gut microflora as a target for energy and metabolic homeostasis. Current Opinion in Clinical Nutrition and Metabolic Care 10 729-734. (doi:10.1097/ MCO.0b013e3282efdebb)

Cani PD, Amar J, Iglesias MA, Poggi M, Knauf C, Bastelica D, Neyrinck AM, Fava F, Tuohy KM, Chabo C, et al. 2007 Metabolic endotoxemia initiates obesity and insulin resistance. Diabetes 56 1761-1772. (doi:10.2337/db06-1491)

Carneiro LA, Magalhaes JG, Tattoli I, Philpott DJ \& Travassos LH 2008 Nod-like proteins in inflammation and disease. Journal of Pathology 214 136-148. (doi:10.1002/path.2271)

Castano L \& Eisenbarth GS 1990 Type-I diabetes: a chronic autoimmune disease of human, mouse, and rat. Annual Review of Immunology $\mathbf{8}$ 647-679. (doi:10.1146/annurev.iy.08.040190.003243)

Cefalu WT 2016 'Prediabetes': are there problems with this label? no, we need heightened awareness of this condition! Diabetes Care 39 1472-1477. (doi:10.2337/dc16-1143)

Cefalu WT, Petersen MP \& Ratner RE 2014 The alarming and rising costs of diabetes and prediabetes: a call for action! Diabetes Care $\mathbf{3 7}$ 3137-3138. (doi:10.2337/dc14-2329)

Charo IF \& Ransohoff RM 2006 The many roles of chemokines and chemokine receptors in inflammation. New England Journal of Medicine 354 610-621. (doi:10.1056/NEJMra052723)

Chatzigeorgiou A, Harokopos V, Mylona-Karagianni C, Tsouvalas E, Aidinis V \& Kamper EF 2010 The pattern of inflammatory/antiinflammatory cytokines and chemokines in type 1 diabetic patients over time. Annals of Medicine 42 426-438. (doi:10.3109/07853890.20 10.495951)

Christen U, McGavern DB, Luster AD, von Herrath MG \& Oldstone MB 2003 Among CXCR3 chemokines, IFN-gamma-inducible protein of $10 \mathrm{kDa}$ (CXC chemokine ligand (CXCL) 10) but not monokine induced by IFN-gamma (CXCL9) imprints a pattern for the subsequent development of autoimmune disease. Journal of Immunology 171 6838-6845. (doi:10.4049/jimmunol.171.12.6838)

Citro A, Cantarelli E, Maffi P, Nano R, Melzi R, Mercalli A, Dugnani E, Sordi V, Magistretti P, Daffonchio L, et al. 2012 CXCR1/2 inhibition enhances pancreatic islet survival after transplantation. Journal of Clinical Investigation 122 3647-3651. (doi:10.1172/JCI63089)

Citro A, Valle A, Cantarelli E, Mercalli A, Pellegrini S, Liberati D, Daffonchio L, Kastsiuchenka O, Ruffini PA, Battaglia M, et al. 2015 CXCR1/2 inhibition blocks and reverses type 1 diabetes in mice. Diabetes 64 1329-1340. (doi:10.2337/db14-0443)

Cnop M, Abdulkarim B, Bottu G, Cunha DA, Igoillo-Esteve M, Masini M, Turatsinze JV, Griebel T, Villate O, Santin I, et al. 2014 RNA sequencing identifies dysregulation of the human pancreatic islet transcriptome by the saturated fatty acid palmitate. Diabetes $\mathbf{6 3}$ 1978-1993. (doi:10.2337/db13-1383)

Coppieters KT, Amirian N, Pagni PP, Baca Jones C, Wiberg A, Lasch S, Hintermann E, Christen U \& von Herrath MG 2013 Functional redundancy of CXCR3/CXCL10 signaling in the recruitment of diabetogenic cytotoxic $\mathrm{T}$ lymphocytes to pancreatic islets in a virally induced autoimmune diabetes model. Diabetes 62 2492-2499. (doi:10.2337/db12-1370)

Corbett JA, Wang JL, Sweetland MA, Lancaster JR Jr \& McDaniel ML 1992 Interleukin 1 beta induces the formation of nitric oxide by beta-cells purified from rodent islets of Langerhans. Evidence for the beta-cell as a source and site of action of nitric oxide. Journal of Clinical Investigation 90 2384-2391. (doi:10.1172/JCI116129)

Corbett JA, Sweetland MA, Wang JL, Lancaster JR Jr \& McDaniel ML 1993 Nitric oxide mediates cytokine-induced inhibition of insulin secretion by human islets of Langerhans. PNAS 90 1731-1735. (doi:10.1073/pnas.90.5.1731)

Corrado A, Ferrari SM, Ferri C, Ferrannini E, Antonelli A \& Fallahi P 2014 Type 1 diabetes and (C-X-C motif) ligand (CXCL) 10 chemokine. Clinical Therapeutics 165 e181-e185.

Coughlan MT, Yap FY, Tong DC, Andrikopoulos S, Gasser A, ThallasBonke V, Webster DE, Miyazaki J, Kay TW, Slattery RM, et al. 2011 Advanced glycation end products are direct modulators of beta-cell function. Diabetes 60 2523-2532. (doi:10.2337/db10-1033)

Cox AJ, West NP \& Cripps AW 2015 Obesity, inflammation, and the gut microbiota. Lancet Diabetes and Endocrinology 3 207-215. (doi:10.1016/S2213-8587(14)70134-2)

Defea K 2008 Beta-arrestins and heterotrimeric G-proteins: collaborators and competitors in signal transduction. British Journal of Pharmacology 153 (Supplement 1) S298-S309. (doi:10.1038/sj. bjp.0707508)

Diana J \& Lehuen A 2014 Macrophages and beta-cells are responsible for CXCR2-mediated neutrophil infiltration of the pancreas during autoimmune diabetes. EMBO Molecular Medicine 6 1090-1104. (doi:10.15252/emmm.201404144)

Diana J, Simoni Y, Furio L, Beaudoin L, Agerberth B, Barrat F \& Lehuen A 2013 Crosstalk between neutrophils, B-1a cells and plasmacytoid dendritic cells initiates autoimmune diabetes. Nature Medicine 19 65-73. (doi:10.1038/nm.3042)

Do OH, Low JT, Gaisano HY \& Thorn P 2014 The secretory deficit in islets from $\mathrm{db} / \mathrm{db}$ mice is mainly due to a loss of responding beta cells. Diabetologia 57 1400-1409. (doi:10.1007/s00125-014-3226-8)

Dogan Y, Akarsu S, Ustundag B, Yilmaz E \& Gurgoze MK 2006 Serum IL-1beta, IL-2, and IL-6 in insulin-dependent diabetic children. Mediators of Inflammation 2006 59206. (doi:10.1155/mi/2006/59206)

Donath MY 2014 Targeting inflammation in the treatment of type 2 diabetes: time to start. Nature Reviews Drug Discovery 13 465-476. (doi:10.1038/nrd4275)

Donath MY, Schumann DM, Faulenbach M, Ellingsgaard H, Perren A \& Ehses JA 2008 Islet inflammation in type 2 diabetes: from metabolic stress to therapy. Diabetes Care 31 (Supplement 2) S161-S164. (doi:10.2337/dc08-s243)

Donga E, Dekkers OM, Corssmit EP \& Romijn JA 2015 Insulin resistance in patients with type 1 diabetes assessed by glucose clamp studies: systematic review and meta-analysis. European Journal of Endocrinology 173 101-109. (doi:10.1530/EJE-14-0911)

Doria A, Patti ME \& Kahn CR 2008 The emerging genetic architecture of type 2 diabetes. Cell Metabolism 8 186-200. (doi:10.1016/j. cmet.2008.08.006)

Dula SB, Jecmenica M, Wu R, Jahanshahi P, Verrilli GM, Carter JD, Brayman KL \& Nunemaker CS 2010 Evidence that low-grade systemic inflammation can induce islet dysfunction as measured by impaired calcium handling. Cell Calcium 48 133-142. (doi:10.1016/j. ceca.2010.07.007)

Eguchi K, Manabe I, Oishi-Tanaka Y, Ohsugi M, Kono N, Ogata F, Yagi N, Ohto U, Kimoto M, Miyake K, et al. 2012 Saturated fatty acid and

Published by Bioscientifica Ltd 
TLR signaling link beta cell dysfunction and islet inflammation. Cell Metabolism 15 518-533. (doi:10.1016/j.cmet.2012.01.023)

Ehses JA, Perren A, Eppler E, Ribaux P, Pospisilik JA, Maor-Cahn R, Gueripel X, Ellingsgaard H, Schneider MK, Biollaz G, et al. 2007 Increased number of islet-associated macrophages in type 2 diabetes. Diabetes 56 2356-2370. (doi:10.2337/db06-1650)

Ehses JA, Lacraz G, Giroix MH, Schmidlin F, Coulaud J, Kassis N, Irminger JC, Kergoat M, Portha B, Homo-Delarche F, et al. 2009 IL-1 antagonism reduces hyperglycemia and tissue inflammation in the type 2 diabetic GK rat. PNAS 106 13998-14003. (doi:10.1073/ pnas.0810087106)

Eldor R, Yeffet A, Baum K, Doviner V, Amar D, Ben-Neriah Y, Christofori G, Peled A, Carel JC, Boitard C, et al. 2006 Conditional and specific NF-kappaB blockade protects pancreatic beta cells from diabetogenic agents. PNAS 103 5072-5077. (doi:10.1073/pnas.0508166103)

Forbes JM, Soderlund J, Yap FY, Knip M, Andrikopoulos S, Ilonen J, Simell O, Veijola R, Sourris KC, Coughlan MT, et al. 2011 Receptor for advanced glycation end-products (RAGE) provides a link between genetic susceptibility and environmental factors in type 1 diabetes. Diabetologia 54 1032-1042. (doi:10.1007/s00125-011-2058-z)

Foulis AK \& Stewart JA 1984 The pancreas in recent-onset type 1 (insulin-dependent) diabetes mellitus: insulin content of islets, insulitis and associated changes in the exocrine acinar tissue. Diabetologia 26 456-461. (doi:10.1007/bf00262221)

Foulis AK, McGill M \& Farquharson MA 1991 Insulitis in type 1 (insulin-dependent) diabetes mellitus in man - macrophages, lymphocytes, and interferon-gamma containing cells. Journal of Pathology 165 97-103. (doi:10.1002/path.1711650203)

Fourlanos S, Narendran P, Byrnes GB, Colman PG \& Harrison LC 2004 Insulin resistance is a risk factor for progression to type 1 diabetes. Diabetologia 47 1661-1667. (doi:10.1007/s00125-004-1507-3)

Frigerio S, Junt T, Lu B, Gerard C, Zumsteg U, Hollander GA \& Piali L 2002 Beta cells are responsible for CXCR3-mediated T-cell infiltration in insulitis. Nature Medicine 8 1414-1420. (doi:10.1038/nm1202-792)

Gepts W 1965 Pathologic anatomy of the pancreas in juvenile diabetes mellitus. Diabetes 14 619-633. (doi:10.2337/diab.14.10.619)

Giannoukakis N, Rudert WA, Trucco M \& Robbins PD 2000 Protection of human islets from the effects of interleukin-1beta by adenoviral gene transfer of an Ikappa B repressor. Journal of Biological Chemistry 275 36509-36513. (doi:10.1074/jbc.M005943200)

Gill RG, Pagni PP, Kufper T, Wasserfall CH, Deng S, Posgai A, Manenkova Y, Hani AB, Straub L, Bernstein P, et al. 2015 A preclinical consortium approach for assessing the efficacy of combined anti-CD3 plus IL-1 blockade in reversing new-onset autoimmune diabetes in NOD mice. Diabetes 65 1310-1316. (doi:10.2337/db15-0492)

Grattan M, Mi QS, Meagher C \& Delovitch TL 2002 Congenic mapping of the diabetogenic locus Idd4 to a 5.2-cM region of chromosome 11 in NOD mice: identification of two potential candidate subloci. Diabetes 51 215-223. (doi:10.2337/diabetes.51.1.215)

Grewal IS, Rutledge BJ, Fiorillo JA, Gu L, Gladue RP, Flavell RA \& Rollins BJ 1997 Transgenic monocyte chemoattractant protein-1 (MCP-1) in pancreatic islets produces monocyte-rich insulitis without diabetes: abrogation by a second transgene expressing systemic MCP-1. Journal of Immunology 159 401-408.

Groom JR \& Luster AD 2011 CXCR3 ligands: redundant, collaborative and antagonistic functions. Immunology and Cell Biology 89 207-215. (doi:10.1038/icb.2010.158)

Hanafusa T \& Imagawa A 2008 Insulitis in human type 1 diabetes. Annals of the New York Academy of Sciences 1150 297-299. (doi:10.1196/annals.1447.052)

Hanifi-Moghaddam P, Kappler S, Seissler J, Muller-Scholze S, Martin S, Roep BO, Strassburger K, Kolb H \& Schloot NC 2006 Altered chemokine levels in individuals at risk of Type 1 diabetes mellitus. Diabetic Medicine 23 156-163. (doi:10.1111/ j.1464-5491.2005.01743.x)
Heise CE, Pahuja A, Hudson SC, Mistry MS, Putnam AL, Gross MM, Gottlieb PA, Wade WS, Kiankarimi M, Schwarz D, et al. 2005 Pharmacological characterization of CXC chemokine receptor 3 ligands and a small molecule antagonist. Journal of Pharmacology and Experimental Therapeutics 313 1263-1271. (doi:10.1124/ jpet.105.083683)

Heitmeier MR, Scarim AL \& Corbett JA 1997 Interferon-gamma increases the sensitivity of islets of Langerhans for inducible nitric-oxide synthase expression induced by interleukin 1. Journal of Biological Chemistry 272 13697-13704. (doi:10.1074/jbc.272.21.13697)

Held TK, Weihua X, Yuan L, Kalvakolanu DV \& Cross AS 1999 Gamma interferon augments macrophage activation by lipopolysaccharide by two distinct mechanisms, at the signal transduction level and via an autocrine mechanism involving tumor necrosis factor alpha and interleukin-1. Infection and Immunity 67 206-212.

Home P, Riddle M, Cefalu WT, Bailey CJ, Bretzel RG, Del Prato S, Leroith D, Schernthaner G, van Gaal L \& Raz I 2014 Insulin therapy in people with type 2 diabetes: opportunities and challenges? Diabetes Care 37 1499-1508. (doi:10.2337/dc13-2743)

Hu C, Ding H, Li Y, Pearson JA, Zhang X, Flavell RA, Wong FS \& Wen L 2015 NLRP3 deficiency protects from type 1 diabetes through the regulation of chemotaxis into the pancreatic islets. PNAS $\mathbf{1 1 2}$ 11318-11323. (doi:10.1073/pnas.1513509112)

Jenh CH, Cox MA, Cui L, Reich EP, Sullivan L, Chen SC, Kinsley D, Qian S, Kim SH, Rosenblum S, et al. 2012 A selective and potent CXCR3 antagonist SCH 546738 attenuates the development of autoimmune diseases and delays graft rejection. BMC Immunology 13 2. (doi:10.1186/1471-2172-13-2)

Jiao X, Zhang N, Xu X, Oppenheim JJ \& Jin T 2005 Ligand-induced partitioning of human CXCR1 chemokine receptors with lipid raft microenvironments facilitates G-protein-dependent signaling. Molecular and Cellular Biology 25 5752-5762. (doi:10.1128/ MCB.25.13.5752-5762.2005)

Johnson AM \& Olefsky JM 2013 The origins and drivers of insulin resistance. Cell 152 673-684. (doi:10.1016/j.cell.2013.01.041)

Jourdan T, Godlewski G, Cinar R, Bertola A, Szanda G, Liu J, Tam J, Han T, Mukhopadhyay B, Skarulis MC, et al. 2013 Activation of the Nlrp3 inflammasome in infiltrating macrophages by endocannabinoids mediates beta cell loss in type 2 diabetes. Nature Medicine 19 1132-1140. (doi:10.1038/nm.3265)

Kahn BB 1998 Type 2 diabetes: when insulin secretion fails to compensate for insulin resistance. Cell 92 593-596. (doi:10.1016/ S0092-8674(00)81125-3)

Karin N, Wildbaum G \& Thelen M 2016 Biased signaling pathways via CXCR3 control the development and function of CD4+ T cell subsets. Journal of Leukocyte Biology 99 857-862. (doi:10.1189/ jlb.2MR0915-441R)

Katancik JA, Sharma A, Radel SJ \& De Nardin E 1997 Mapping of the extracellular binding regions of the human interleukin-8 type B receptor. Biochemical and Biophysical Research Communications 232 663-668. (doi:10.1006/bbrc.1997.6352)

Katancik JA, Sharma A \& de Nardin E 2000 Interleukin 8, neutrophilactivating peptide- 2 and GRO-alpha bind to and elicit cell activation via specific and different amino acid residues of CXCR2. Cytokine $\mathbf{1 2}$ 1480-1488. (doi:10.1006/cyto.2000.0742)

Kenty JH \& Melton DA 2015 Testing pancreatic islet function at the single cell level by calcium influx with associated marker expression. PLOS ONE 10 e0122044. (doi:10.1371/journal.pone.0122044)

Khan SM, Sleno R, Gora S, Zylbergold P, Laverdure JP, Labbe JC, Miller GJ \& Hebert TE 2013 The expanding roles of Gbetagamma subunits in $\mathrm{G}$ protein-coupled receptor signaling and drug action. Pharmacological Reviews 65 545-577. (doi:10.1124/pr.111.005603)

Kouroumalis A, Nibbs RJ, Aptel H, Wright KL, Kolios G \& Ward SG 2005 The chemokines CXCL9, CXCL10, and CXCL11 differentially stimulate $\mathrm{G}$ alpha i-independent signaling and actin responses in 
human intestinal myofibroblasts. Journal of Immunology 175 5403-5411. (doi:10.4049/jimmunol.175.8.5403)

Kreider KE \& Lien LF 2015 Transitioning safely from intravenous to subcutaneous insulin. Current Diabetes Reports 15 23. (doi:10.1007/ s11892-015-0595-4)

Kuttler B, Wanka H, Kloting N, Gerstmayer B, Volk HD, Sawitzki B \& Ritter T 2007 Ex vivo gene transfer of viral interleukin-10 to BB rat islets: no protection after transplantation to diabetic BB rats. Journal of Cellular and Molecular Medicine 11 868-880. (doi:10.1111/j.15824934.2007.00059.x)

Lasch S, Muller P, Bayer M, Pfeilschifter JM, Luster AD, Hintermann E \& Christen U 2015 Anti-CD3/anti-CXCL10 antibody combination therapy induces a persistent remission of type 1 diabetes in two mouse models. Diabetes 64 4198-4211. (doi:10.2337/db15-0479)

Lee YS, Morinaga H, Kim JJ, Lagakos W, Taylor S, Keshwani M, Perkins G, Dong H, Kayali AG, Sweet IR, et al. 2013 The fractalkine/CX3CR1 system regulates beta cell function and insulin secretion. Cell 153 413-425. (doi:10.1016/j.cell.2013.03.001)

Liu L, Belkadi A, Darnall L, Hu T, Drescher C, Cotleur AC, PadovaniClaudio D, He T, Choi K, Lane TE, et al. 2010 CXCR2-positive neutrophils are essential for cuprizone-induced demyelination: relevance to multiple sclerosis. Nature Neuroscience 13 319-326. (doi:10.1038/nn.2491)

Lopes M, Kutlu B, Miani M, Bang-Berthelsen CH, Storling J, Pociot F, Goodman N, Hood L, Welsh N, Bontempi G, et al. 2014 Temporal profiling of cytokine-induced genes in pancreatic beta-cells by metaanalysis and network inference. Genomics 103 264-275. (doi:10.1016/j.ygeno.2013.12.007)

Lundberg M, Krogvold L, Kuric E, Dahl-Jorgensen K \& Skog O 2016 Expression of interferon-stimulated genes in insulitic pancreatic islets of patients recently diagnosed with type 1 diabetes. Diabetes $\mathbf{6 5}$ 3104-3110. (doi:10.2337/db16-0616)

Luttrell LM \& Lefkowitz RJ 2002 The role of beta-arrestins in the termination and transduction of G-protein-coupled receptor signals. Journal of Cell Science 115 455-465.

Marchese A, Paing MM, Temple BR \& Trejo J 2008 G protein-coupled receptor sorting to endosomes and lysosomes. Annual Review of Pharmacology and Toxicology 48 601-629. (doi:10.1146/annurev. pharmtox.48.113006.094646)

Martin AP, Alexander-Brett JM, Canasto-Chibuque C, Garin A, Bromberg JS, Fremont DH \& Lira SA 2007 The chemokine binding protein M3 prevents diabetes induced by multiple low doses of streptozotocin. Journal of Immunology 178 4623-4631. (doi:10.4049/ jimmunol.178.7.4623)

Martin AP, Grisotto MG, Canasto-Chibuque C, Kunkel SL, Bromberg JS, Furtado GC \& Lira SA 2008 a Islet expression of M3 uncovers a key role for chemokines in the development and recruitment of diabetogenic cells in NOD mice. Diabetes 57 387-394. (doi:10.2337/ db07-1309)

Martin AP, Rankin S, Pitchford S, Charo IF, Furtado GC \& Lira SA $2008 b$ Increased expression of CCL2 in insulin-producing cells of transgenic mice promotes mobilization of myeloid cells from the bone marrow, marked insulitis, and diabetes. Diabetes 57 3025-3033. (doi:10.2337/db08-0625)

Martinez Munoz L, Lucas P, Navarro G, Checa AI, Franco R, Martinez AC, Rodriguez-Frade JM \& Mellado M 2009 Dynamic regulation of CXCR1 and CXCR2 homo- and heterodimers. Journal of Immunology 183 7337-7346. (doi:10.4049/jimmunol.0901802)

Martinon F 2008 Detection of immune danger signals by NALP3. Journal of Leukocyte Biology 83 507-511. (doi:10.1189/jlb.0607362)

Mocsai A 2013 Diverse novel functions of neutrophils in immunity, inflammation, and beyond. Journal of Experimental Medicine 210 1283-1299. (doi:10.1084/jem.20122220)

Moran A, Bundy B, Becker DJ, DiMeglio LA, Gitelman SE, Goland R, Greenbaum CJ, Herold KC, Marks JB, Raskin P, et al. 2013
Interleukin-1 antagonism in type 1 diabetes of recent onset: two multicentre, randomised, double-blind, placebo-controlled trials. Lancet 381 1905-1915. (doi:10.1016/S0140-6736(13)60023-9)

Muoio DM \& Newgard CB 2008 Mechanisms of disease: molecular and metabolic mechanisms of insulin resistance and beta-cell failure in type 2 diabetes. Nature Reviews Molecular Cell Biology 9 193-205. (doi:10.1038/nrm2327)

Murphy PM \& Tiffany HL 1991 Cloning of complementary DNA encoding a functional human interleukin-8 receptor. Science $\mathbf{2 5 3}$ 1280-1283. (doi:10.1126/science.1891716)

Nowotny K, Jung T, Hohn A, Weber D \& Grune T 2015 Advanced glycation end products and oxidative stress in type 2 diabetes mellitus. Biomolecules 5 194-222. (doi:10.3390/biom5010194)

Nunemaker CS, Chung HG, Verrilli GM, Corbin KL, Upadhye A \& Sharma PR 2014 Increased serum CXCL1 and CXCL5 are linked to obesity, hyperglycemia, and impaired islet function. Journal of Endocrinology 222 267-276. (doi:10.1530/JOE-14-0126)

Pierce KL, Premont RT \& Lefkowitz RJ 2002 Seven-transmembrane receptors. Nature Reviews Molecular Cell Biology 3 639-650. (doi:10.1038/nrm908)

Purohit J, Hu P, Burke SJ, Collier JJ, Chen J \& Zhao L 2013 The effects of NOD activation on adipocyte differentiation. Obesity 21 737-747. (doi:10.1002/oby.20275)

Qureshi FM, Dejene EA, Corbin KL \& Nunemaker CS 2015 Stressinduced dissociations between intracellular calcium signaling and insulin secretion in pancreatic islets. Cell Calcium 57 366-375. (doi:10.1016/i.ceca.2015.03.002)

Raghuwanshi SK, Su Y, Singh V, Haynes K, Richmond A \& Richardson RM 2012 The chemokine receptors CXCR1 and CXCR2 couple to distinct $\mathrm{G}$ protein-coupled receptor kinases to mediate and regulate leukocyte functions. Journal of Immunology 189 2824-2832. (doi:10.4049/jimmunol.1201114)

Rajagopal S 2013 Quantifying biased agonism: understanding the links between affinity and efficacy. Nature Reviews Drug Discovery 12483. (doi:10.1038/nrd3954-c1)

Rajagopal S, Bassoni DL, Campbell JJ, Gerard NP, Gerard C \& Wehrman TS 2013 Biased agonism as a mechanism for differential signaling by chemokine receptors. Journal of Biological Chemistry $\mathbf{2 8 8}$ 35039-35048. (doi:10.1074/jbc.M113.479113)

Ramadan JW, Steiner SR, O'Neill CM \& Nunemaker CS 2011 The central role of calcium in the effects of cytokines on beta-cell function: implications for type 1 and type 2 diabetes. Cell Calcium $\mathbf{5 0}$ 481-490. (doi:10.1016/j.ceca.2011.08.005)

Raman D, Sai J, Hawkins O \& Richmond A 2014 Adaptor protein2 (AP2) orchestrates CXCR2-mediated cell migration. Traffic 15 451-469. (doi:10.1111/tra.12154)

Rehman KK, Bertera S, Bottino R, Balamurugan AN, Mai JC, Mi Z, Trucco M \& Robbins PD 2003 Protection of islets by in situ peptidemediated transduction of the Ikappa B kinase inhibitor Nemobinding domain peptide. Journal of Biological Chemistry $\mathbf{2 7 8}$ 9862-9868. (doi:10.1074/jbc.M207700200)

Rhode A, Pauza ME, Barral AM, Rodrigo E, Oldstone MB, von Herrath MG \& Christen U 2005 Islet-specific expression of CXCL10 causes spontaneous islet infiltration and accelerates diabetes development. Journal of Immunology 175 3516-3524. (doi:10.4049/jimmunol.175.6.3516)

Richardson SJ, Willcox A, Bone AJ, Foulis AK \& Morgan NG 2009 Isletassociated macrophages in type 2 diabetes. Diabetologia $\mathbf{5 2}$ 1686-1688. (doi:10.1007/s00125-009-1410-z)

Richardson SJ, Rodriguez-Calvo T, Gerling IC, Mathews CE, Kaddis JS, Russell MA, Zeissler M, Leete P, Krogvold L, Dahl-Jorgensen K, et al. 2016 Islet cell hyperexpression of HLA class I antigens: a defining feature in type 1 diabetes. Diabetologia 59 2448-2458. (doi:10.1007/ s00125-016-4067-4)

Rink JS, Chen X, Zhang X \& Kaufman DB 2012 Conditional and specific inhibition of NF-kappaB in mouse pancreatic beta cells prevents http://jme.endocrinology-journals.org

DOI: 10.1530/JME-17-0042
() 2017 Society for Endocrinology Printed in Great Britain
Published by Bioscientifica Ltd 
cytokine-induced deleterious effects and improves islet survival posttransplant. Surgery 151 330-339. (doi:10.1016/j. surg.2011.07.011)

Rosa JS, Flores RL, Oliver SR, Pontello AM, Zaldivar FP \& Galassetti PR 2008 Sustained IL-1alpha, IL-4, and IL- 6 elevations following correction of hyperglycemia in children with type 1 diabetes mellitus. Pediatric Diabetes 9 9-16. (doi:10.1111/j.13995448.2007.00243.x)

Rutkowsky JM, Knotts TA, Ono-Moore KD, McCoin CS, Huang S, Schneider D, Singh S, Adams SH \& Hwang DH 2014 Acylcarnitines activate proinflammatory signaling pathways. American Journal of Physiology: Endocrinology and Metabolism 306 E1378-E1387. (doi:10.1152/ajpendo.00656.2013)

Sajadi SM, Khoramdelazad H, Hassanshahi G, Rafatpanah H, Hosseini J, Mahmoodi M, Arababadi MK, Derakhshan R, Hasheminasabzavareh R, Hosseini-Zijoud SM, et al. 2013 Plasma levels of CXCL1 (GROalpha) and CXCL10 (IP-10) are elevated in type 2 diabetic patients: evidence for the involvement of inflammation and angiogenesis/ angiostasis in this disease state. Clinical Laboratory 59 133-137. (doi:10.7754/clin.lab.2012.120225)

Samuel VT \& Shulman GI 2016 The pathogenesis of insulin resistance: integrating signaling pathways and substrate flux. Journal of Clinical Investigation 126 12-22. (doi:10.1172/JCI77812)

Sanchez I, Reynoso-Camacho R \& Salgado LM 2015 The diet-induced metabolic syndrome is accompanied by whole-genome epigenetic changes. Genes and Nutrition 10 471. (doi:10.1007/s12263-0150471-5)

Sarkar SA, Lee CE, Victorino F, Nguyen TT, Walters JA, Burrack A, Eberlein J, Hildemann SK \& Homann D 2012 Expression and regulation of chemokines in murine and human type 1 diabetes. Diabetes 61 436-446. (doi:10.2337/db11-0853)

Schulthess FT, Paroni F, Sauter NS, Shu L, Ribaux P, Haataja L, Strieter RM, Oberholzer J, King CC \& Maedler K 2009 CXCL10 impairs beta cell function and viability in diabetes through TLR4 signaling. Cell Metabolism 9 125-139. (doi:10.1016/j.cmet.2009.01.003)

Sharabiani MT, Vermeulen R, Scoccianti C, Hosnijeh FS, Minelli L, Sacerdote C, Palli D, Krogh V, Tumino R, Chiodini P, et al. 2011 Immunologic profile of excessive body weight. Biomarkers $\mathbf{1 6}$ 243-251. (doi:10.3109/1354750X.2010.547948)

Sharma RB, O'Donnell AC, Stamateris RE, Ha B, McCloskey KM, Reynolds PR, Arvan P \& Alonso LC 2015 Insulin demand regulates beta cell number via the unfolded protein response. Journal of Clinical Investigation 125 3831-3846. (doi:10.1172/JCI79264)

Shenoy SK \& Lefkowitz RJ 2005 Receptor regulation: beta-arrestin moves up a notch. Nature Cell Biology 7 1159-1161. (doi:10.1038/ncb12051159)

Shigihara T, Oikawa Y, Kanazawa Y, Okubo Y, Narumi S, Saruta T \& Shimada A 2006 Significance of serum CXCL10/IP-10 level in type 1 diabetes. Journal of Autoimmunity 26 66-71. (doi:10.1016/j. jaut.2005.09.027)

Shimabukuro M, Zhou YT, Lee Y \& Unger RH 1998 Troglitazone lowers islet fat and restores beta cell function of Zucker diabetic fatty rats. Journal of Biological Chemistry 273 3547-3550. (doi:10.1074/ jbc.273.6.3547)

Sierro F, Biben C, Martinez-Munoz L, Mellado M, Ransohoff RM, Li M, Woehl B, Leung H, Groom J, Batten M, et al. 2007 Disrupted cardiac development but normal hematopoiesis in mice deficient in the second CXCL12/SDF-1 receptor, CXCR7. PNAS 104 14759-14764. (doi:10.1073/pnas.0702229104)

Straczkowski M, Dzienis-Straczkowska S, Stepien A, Kowalska I, Szelachowska M \& Kinalska I 2002 Plasma interleukin-8 concentrations are increased in obese subjects and related to fat mass and tumor necrosis factor-alpha system. Journal of Clinical
Endocrinology and Metabolism 87 4602-4606. (doi:10.1210/jc.2002020135)

Sumpter KM, Adhikari S, Grishman EK \& White PC 2011 Preliminary studies related to anti-interleukin-1beta therapy in children with newly diagnosed type 1 diabetes. Pediatric Diabetes 12 656-667. (doi:10.1111/j.1399-5448.2011.00761.x)

Syrovatkina V, Alegre KO, Dey R \& Huang XY 2016 Regulation, signaling, and physiological functions of G-proteins. Journal of Molecular Biology 428 3850-3868. (doi:10.1016/j.jmb.2016.08.002)

Takahashi K, Ohara M, Sasai T, Homma H, Nagasawa K, Takahashi T, Yamashina M, Ishii M, Fujiwara F, Kajiwara T, et al. 2011 Serum CXCL1 concentrations are elevated in type 1 diabetes mellitus, possibly reflecting activity of anti-islet autoimmune activity. Diabetes/Metabolism Research and Reviews 27 830-833. (doi:10.1002/ dmrr.1257)

Talukdar S, Oh da Y, Bandyopadhyay G, Li D, Xu J, McNelis J, Lu M, Li P, Yan Q, Zhu Y, et al. 2012 Neutrophils mediate insulin resistance in mice fed a high-fat diet through secreted elastase. Nature Medicine $\mathbf{1 8}$ 1407-1412. (doi:10.1038/nm.2885)

Thompson BD, Jin Y, Wu KH, Colvin RA, Luster AD, Birnbaumer L \& Wu MX 2007 Inhibition of G alpha i2 activation by G alpha i3 in CXCR3-mediated signaling. Journal of Biological Chemistry $\mathbf{2 8 2}$ 9547-9555. (doi:10.1074/jbc.M610931200)

Trettel F, Di Bartolomeo S, Lauro C, Catalano M, Ciotti MT \& Limatola C 2003 Ligand-independent CXCR2 dimerization. Journal of Biological Chemistry 278 40980-40988. (doi:10.1074/jbc. M306815200)

Unger RH 2003 Lipid overload and overflow: metabolic trauma and the metabolic syndrome. Trends in Endocrinology and Metabolism 14 398-403. (doi:10.1016/j.tem.2003.09.008)

Unger RH \& Orci L 2000 Lipotoxic diseases of nonadipose tissues in obesity. International Journal of Obesity and Related Metabolic Disorders 24 (Supplement 4) S28-S32. (doi:10.1038/sj.ijo.0801498)

Van Raemdonck K, Van den Steen PE, Liekens S, Van Damme J \& Struyf S 2015 CXCR3 ligands in disease and therapy. Cytokine and Growth Factor Reviews 26 311-327. (doi:10.1016/j. cytogfr.2014.11.009)

Veenstra M \& Ransohoff RM 2012 Chemokine receptor CXCR2: physiology regulator and neuroinflammation controller? Journal of Neuroimmunology 246 1-9. (doi:10.1016/j.jneuroim.2012.02.016)

Wallberg M \& Cooke A 2013 Immune mechanisms in type 1 diabetes. Trends in Immunology 34 583-591. (doi:10.1016/j.it.2013.08.005)

Watts AO, Scholten DJ, Heitman LH, Vischer HF \& Leurs R 2012 Labelfree impedance responses of endogenous and synthetic chemokine receptor CXCR3 agonists correlate with Gi-protein pathway activation. Biochemical and Biophysical Research Communications 419 412-418. (doi:10.1016/j.bbrc.2012.02.036)

Waugh DJ \& Wilson C 2008 The interleukin-8 pathway in cancer. Clinical Cancer Research 14 6735-6741. (doi:10.1158/1078-0432.CCR07-4843)

Welzen-Coppens JM, van Helden-Meeuwsen CG, Leenen PJ, Drexhage HA \& Versnel MA 2013 The kinetics of plasmacytoid dendritic cell accumulation in the pancreas of the NOD mouse during the early phases of insulitis. PLOS ONE 8 e55071. (doi:10.1371/journal. pone.0055071)

Willcox A, Richardson SJ, Bone AJ, Foulis AK \& Morgan NG 2009 Analysis of islet inflammation in human type 1 diabetes. Clinical and Experimental Immunology 155 173-181. (doi:10.1111/j.13652249.2008.03860.x)

Wilson S, Wilkinson G \& Milligan G 2005 The CXCR1 and CXCR2 receptors form constitutive homo- and heterodimers selectively and with equal apparent affinities. Journal of Biological Chemistry 280 28663-28674. (doi:10.1074/jbc.M413475200) http://jme.endocrinology-journals.org

DOI: 10.1530/JME-17-0042
(C) 2017 Society for Endocrinology Printed in Great Britain
Published by Bioscientifica Ltd 
Wisler JW, Xiao K, Thomsen AR \& Lefkowitz RJ 2014 Recent developments in biased agonism. Current Opinion in Cell Biology 27 18-24. (doi:10.1016/j.ceb.2013.10.008)

Yamada Y, Okubo Y, Shimada A, Oikawa Y, Yamada S, Narumi S, Matsushima K \& Itoh H 2012 Acceleration of diabetes development in CXC chemokine receptor 3 (CXCR3)-deficient NOD mice. Diabetologia 55 2238-2245. (doi:10.1007/s00125-012-2547-8)
Zak KP, Popova VV, Mel'nichenko SV, Tron'ko EN \& Man'kovskii BN 2010 The level of circulating cytokines and chemokines in the preclinical and early clinical stages of type IA diabetes mellitus development. Terapevticheskii Arkhiv 82 10-15.

Zweemer AJ, Toraskar J, Heitman LH \& AP IJ 2014 Bias in chemokine receptor signalling. Trends in Immunology 35 243-252. (doi:10.1016/j. it.2014.02.004)

Received in final form 31 March 2017

Accepted 18 April 2017

Accepted Preprint published online 18 April 2017
Published by Bioscientifica Ltd. 